\title{
QUESTIONS AND SCIENCE CONTENTS PREFERRED BY EARLY CHILDHOOD EDUCATION TEACHERS IN TRAINING
}

\author{
Adrián Ponz Miranda ${ }^{1,2}$, \& Beatriz Carrasquer Álvarez ${ }^{1}$ \\ ${ }^{1}$ Department of Didactics of Experimental Sciences, University of Zaragoza (Spain) \\ ${ }^{2}$ Beagle Group, Research in Didactics of Experimental Sciences, University of Zaragoza (Spain)
}

\begin{abstract}
In scientific education, the inquiry approach through questions is a key tool that allows establishing relationships between the facts or phenomena under study to involve students. It fosters self-learning through problem solving, dialogue, discussion, reasoned argumentation, free thought, prediction, experimentation, explanation, reflection, and evaluation. In the teaching of sciences in early childhood education, it is important to establish links between internships in schools and structure of university lectures, fostering the transition to school research. Learning of future teachers must be diverse and reflexive. The role of evaluation as a regulator of the teaching-learning process should be considered, as well as to address topics that provide resources and knowledge to future teachers, including to use such scientific knowledge in everyday contexts and provide them with a critical vision on certain topics of interest.

In this research, we have considered to know which questions and contents arouse curiosity among Early Childhood Education teachers in training and what kind of questions and contents they would propose to work in the classroom for the learning of sciences. Reasons (convictions, motivations) of their preferences have been investigated, as far as possible, to focus their development as teachers. Ad hoc questionnaires for this study have been carried out in the last two courses (2017-18, 2018-19), and filled each of them in by around 58 students of "The Nature Sciences in Early Childhood Education" of the Degree in Teaching. Most of the students considered as interesting content to work in the classroom objects and materials of the environment and water and air, and less than half considered living beings. The human body and living beings stand out as the preferred topics. The presence of chosen contents or not in the curriculum seems to be an important factor in the decision of students. Almost all of the students considered that they need to learn scientific contents together with strategies and teaching techniques on how to teach, both to be able to put them into practice and to teach students well satisfying curiosity that may arise in the classroom. And to acquire a greater conceptual base of its own as well.

In many cases, preferences as students include more complex issues than those chosen to deal with children. In relation to the questions that they considered they would make children, based on their own experience, including school practices, the most mentioned ones were about the water cycle and water states, physical phenomena and living beings.
\end{abstract}

Keywords: Questions, school research, teaching of sciences, early childhood education.

\section{Introduction}

Teachers need a minimun knowledge and acquired competences to engage children in science practices. That is the reason why they should learn to teach sciences by developing an evidence-based framework including discussion, reasoned argumentation, free thought, prediction, experimentation, explanation, reflection, and evaluation (Crawford and Capps, 2016; Rivero, Solís, Martín, Azcárate, and Porlán, 2017). Learning of future teachers must be diverse and reflexive, representing a certain degree of approximation to knowledge that you want to promote, but without matching it (Rivero et al, 2017). Topics that provide resources and knowledge to future teachers to help them to understand the role of the teacher as a mediator between students and science, the role of scientific education in citizen education, and ensuring the maximum interrelation between theory and practice, should be addressed among other issues (Bonil and Márquez, 2011). Therefore, the role of Didactics of Experimental Sciences in teacher training should consist of to encourage so much argumentation as the transfer of facts and events of everyday life to the classroom, as an essential part of said training. We should have into account that it is 
necessary to stimulate our students the skills of reasoning and critical thinking, to give account of the multitude of situations that surround them in which sciences have a fundamental role (Cantó, Pro y Solves, 2017). To investigate the reasons of their preferences to work sciences in the classroom constitude a key point to focus their development as teachers.

Amos (2002) points out that a fifth of what a teacher says in a classroom can be in the form of questions. If they ask open-ended questions, they allow their students to think freely and flexibly, to express their own ideas and thoughts, without worrying that they have to give a correct answer and, on the other hand, they promote successful discussions that stimulate student participation (Harlen, 1999). Several authors suggest identifying researchable questions as a first step to guide the research work (Ben David and Zohar 2009; Caamaño 2012; Windschitl, Thompson and Braaten 2008). Questions can encourage students to move from mere affirmations to the development of prediction, experimentation and explanation, since they favour the generation of a cascade of cognitive activities, which allow them to build through pieces their knowledge or resolving comprehension conflicts (Chin and Brown, 2002).

\section{Objectives}

This research aims to improve the skills of students of the Teaching Degree in Early Childhood Education, necessary for them to address in the future, as teachers, the teaching of scientific content in this educational stage. First goal consisted on to know which science questions and contents arouse curiosity among Early Childhood Education teachers in training and what kind of questions and contents they would propose to work in the classroom for the learning of sciences. Then, from the evaluation results, including the convictions and motivations of students preferences, some conclusions can be drawn. They can be of reflection and interest for the teaching staff of other subjects and for the own managers of the degrees, such as the components of the Commissions of the qualifications of Teaching.

\section{Methods}

First, the type and amount of tests to be carried out was decided. Two ad hoc questionnaires were created in Google Forms, as the course progresses, advertising them in the same classes of the subject and through Moodle as well. Possibilities of data handling and diversity of type of issues were considered. The errors or difficulties in the realization of the tests were corrected quickly.

One of the questionnaires was focussed to which questions arouse curiosity among Early Childhood Education teachers in training and what kind of questions they would propose to work in the classroom for the learning of sciences. It was filled in by 59 students.

The other was focussed to which contents arouse curiosity among Early Childhood Education teachers in training and what kind of contents they would propose to work in the classroom for the learning of sciences. It was filled in by 57 students.

Open-ended and closed questions were raised in both questionnaires, such as:

- What contents of Experimental Sciences should be taught in the stage of Early Childhood Education?

- What content should the university teach Teaching students of that degree?

- The contents that the university must teach to the teaching students must be exactly the same as those of the children in the school? Why?

- Do you think that the university should not teach any kind of scientific content together with teaching strategies and didactic techniques on how to teach these contents to children? Why?

- $\quad$ As a future teacher of children, what is the topic or scientific content that you would most like to work with your students, regardless of whether or not they are in the curriculum?

- What question would you like to ask personally to satisfy your curiosity about the content or scientific phenomenon that most attracts your attention?

- Write an example question, about a science content that you think a student could make when you are their teacher. What have you relied on to do it?

- $\quad$ Encourage the students of Children to ask questions about natural phenomena, do you think it is important for them to acquire scientific knowledge?

- What is the best time to generate questions in the students?

If you did not get any student to ask you a question about the phenomenon you want them to learn, what would you do to achieve your goal (what kind of activity or pedagogical technique would you use, etc.)?

Collected data were compiled in excel sheets to be evaluated. 


\section{Results}

About what contents of Experimental Sciences should be taught in the stage of Early Childhood Education, most mentioned ones were matter and materials (for $70 \%$ of students), water and air, and living beings (for $30 \%$ of the students). To the question "Would you change the choice of contents that you have made in the two previous questions", about $40 \%$ answered affirmatively. Then, it could be interpreted that the presence of the content or not in the curriculum is an important factor in the decision of students.

Only $21 \%$ of students think that contents that teachers in training have to acquire at the university must be exactly equal to those of the children. Some reasons given by students who desagree with this affirmation were:

- "Our duty is to teach, for which we must learn more knowledge in order to better teach."

- "Because they have to add content referring to teaching and pedagogy."

- "Because at the university they should teach us teaching methods."

- "Children of Childhood Education do not have why to know all the contents that we know since they will not be able to understand some concepts."

- "We should adapt contents to the evolutionary development of the students."

- "Students must learn how to teach these contents, in addition to the fact that the university must provide many transversal contents on these subjects."

- "Because teachers must be better trained and also continue learning daily".

- "To know more about what is being done."

- "To know how to interpret children results."

About a $95 \%$ believe that university should teach scientific contents together with strategies and teaching techniques on how to teach. Main reasons given by students were based on the need to learn content before teaching them, both to be able to put them into practice and to be able to teach the students well and satisfy curiosity that may arise in the classroom. And to acquire a greater conceptual base of its own as well. To the specific question of what type of content should be taught at the university to the students of the Teaching degree of Childhood education, students mentioned some strategies and teaching techniques, among others:

- "The construction of the knowledge of the natural environment in the contexts of Infantile Education." "Implications of the investigation in Didactics of the Sciences in the design, development and evaluation of learning activities in Early Childhood Education."

- "Difficulties and communication strategies in the context of the Early Childhood classroom."

- "Creation of contexts for the observation and posing of problematic situations."

- "Experimentation in science classes."

- "Skills for the elaboration of conclusions."

- "Skills for the communication and discussion of the built knowledge."

- "Teaching resources for the teaching of the physical-natural environment."

- "Theories of Education (Pedagogy) applied to the Didactics of the Sciences."

- "Educational psychology applied to the Teaching of the Sciences, among others contents."

Preferred topics and scientific contents by students to work with children were human body, living beings and animals, and ecosistems-nature. Other minoritay topics were universe, Day-Night, water cicle, or fungi. In their preferences as students, they include some more complex issues such as the Big-bang, Earth, Astronomy, or Cells. Some results are included in Figure 1.

The totality of the students agreed that to animate children of Infantile to make questions about natural phenomena it is important so that they acquire scientific knowledge. More than $90 \%$ agree that the questions should be posed by the children themselves and not by teachers. Most of the students (almost $60 \%$ ) affirmed that questions should be generated in children at any time of the school day. The others think that the best time to generate questions in the students is just beginning the school day (20\%) to encourage curiosity during the day, or at the end (20\%) as closure and reflection of the day. From their experience including school practices students affirmed that questions which children would ask are about water cycle and water changes (30\%), physical phenomena such as flotation or gravity (14\%), and animals and vegetables (14\%). Another $7 \%$ propose other topics like day and night, flotation or rainbow formation. Only a 9\% whould to know more about didactic methodologies and experimentation and applicability in infancy. Data confirms that they do not give enough importance to acquire didactic methods neither to the content of the contents of the children nor to applied research. Still there is a $17 \%$ who do not have interest to satisfy their curiosity about any content or scientific phenomenon. 
About activities or pedagogical technique to get children to ask questions about an specific phenomenon, students proposed experiments, manipulative models, videos, contact with environment, games and inquiry.

Figure 1. Preferred topics and scientific contents to work with children.

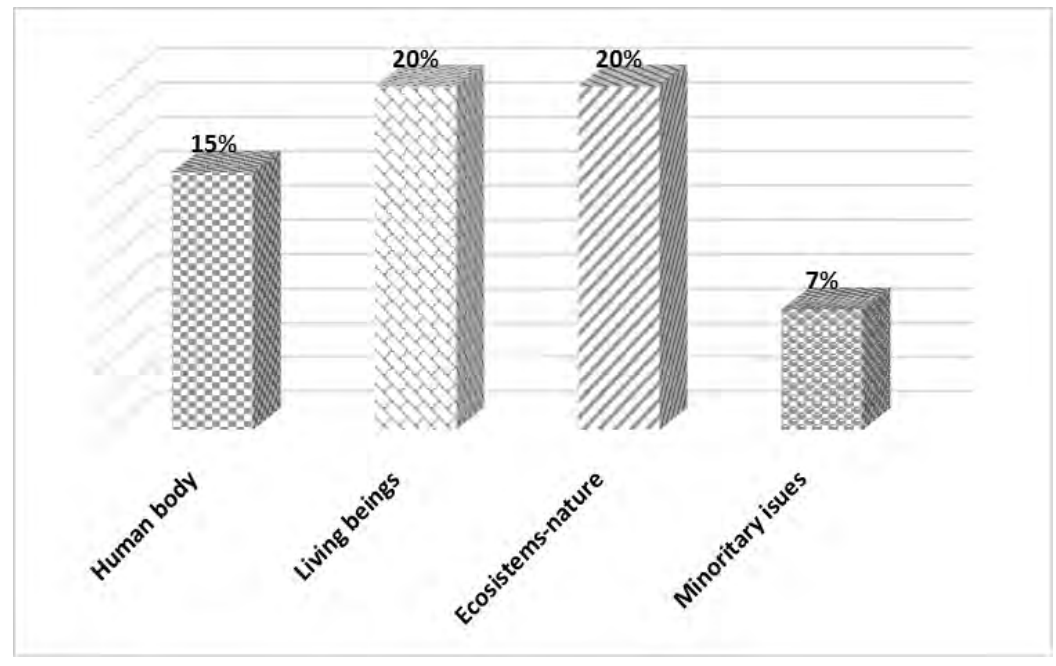

\section{Discussion and conclusion}

Following the order of exposition of results, to answer the question "what contents of Experimental Sciences should be taught in the stage of Early Childhood Education", the presence of the content or not in the curriculum seems to be an important factor in the decision of students. About a 95\% of teachers in training believe that university should teach scientific contents together with strategies and teaching techniques on how to teach. Students think that it is needed to improve the knowledge of teachers both in science and their didactics. They highlighted the construction of the knowledge, implications and designs of research, teaching resources, and skills in communication, experimentation, pedagogy, psychology all applied to the Teaching of the Sciences, among others contents. Initial scientific training influences the attitude of future teachers, being more positive in aspects such as their confidence in teaching subjects and their knowledge about the resources to work with children (Mazas and Brazo, 2018). Future teachers agree that their training needs should be addressed and these are also of didactic type. For this it would be necessary to provide them throughout its training with both resources and practical experiences, not only to acquire the necessary knowledge, but also to know how to use them in the professional and personal field (Cantó, de Pro and Solves, 2017). Contents of the area of self-knowledge and knowledge of the environment (human body, living beings, animals, ecosistems, nature) are those with greater presence in the answers, with shows that students considered its importance in Chilhood Education stage, agreeing with research results of Cantó, de Pro and Solves (2016).

It is worth to say that students proposed experiments, manipulative models, videos, outings to the environment, games and inquiry activities or pedagogical technique to get children to ask questions about an specific phenomenon. They give importance to work sciences at the classroom in a practical way as it was already as stated by some authors (Mazas and Bravo, 2018) unlike that shows in other research (Cantó, de Pro and Solves Matarredona, 2017).

Students agreed that to encourage children to ask themselves questions on the natural phenomena it is important for them to acquire scientific knowledge. Most of the students affirmed that questions should be generated in children at any time of the school day. In accordance with what has been stated in previous works (Ponz and Carrasquer, 2018), it is fundamental for the meaningful learning of the scientific contents, in spite of not having carried out any type of educational activity in their previous training in which they were asked to ask questions in relation to a phenomenon. Despite showing great interest in using this methodology, however, they do not take much it into practice. About questions which students affirmed that children would ask are not inquiry questions. Only $3 \%$ proposed questions from which it is possible to design a methodology to obtain data. This idea has already been presented in other works in which the great challenge of raising questions that give rise to investigations (Ponz and Carrasquer, 2018; Ferrés-Gurt, 2017).

The experience can be implemented in any area of knowledge and with different uses, although, in this case, it has been applied in a scientific area. Results and conclusions will be of interest to the 
students themselves, the development of the subject and undoubtedly also to bodies managing these degrees and others of the University of Zaragoza. Data confirms that there is still a lack of teachers in training interest not only to acquire didactic methods but also to applied research. There is an important percentage who do not have interest to satisfy their curiosity about any content or scientific phenomenon. The innovation lies in the detection and acceptance by the students of the acquisition of competencies that, at present do not believe necessary, mainly because they are not objectively aware of their own deficiencies. It requires effort on the part of the student and acceptance of the same to conclude with the satisfaction of learning. It is necessary to take some decision and execute institutional actions in various areas that lead to the improvement in the training of the teaching students. We think that results obtained in this research can help in it.

\section{Acknowledgments}

This study was supported by Project EDU2016-76743-P (MINECO) and Project CienciaTE3 (2018/B001; Fundación Universitaria Antonio Gargallo). A. Ponz is member of Group for Applied Research "Beagle" (IUCA, Universidad de Zaragoza) financed by the Government of Aragon (S27_17R) and co-financed with FEDER 2014-2020 "Building Europe from Aragon".

\section{References}

Amos, S. (2002). Teachers' questions in the science classroom. En: Amos, S., Booham, R. (eds.). Aspects of teaching secondary science. London: The Open University.

Ben David, A., Zohar, A. (2009) Contribution of Meta-strategic Knowledge to Scientific Inquiry Learning. International Journal of Science Education 31(12), 1657-1682.

Bonil Gargallo, J. and Màrquez Bargalló, C. (2011). What sciences class experiences do future teachers report? Implications for science teachers education. Revista de Educación, 354, 447-472.

Caamaño, A. (2012) ¿Cómo introducir la indagación en el aula? Alambique. Didáctica de Las Ciencias 70, 83-91.

Cantó Doménech, J., Pro Bueno, A. de, Solves Matarredona, J. (2016). Which sciences are taught and in what manner in Early Childhood education classes? The perception of teachers during initial training. Enseñanza de las ciencias, 34.3, 25-50.

Cantó Doménech, J., Pro Bueno, A. de, Solves Matarredona, J. (2017). ¿Cómo utilizan los conocimientos en ciencias los futuros maestros de educación infantil ante una información escrita?. Enseñanza de las ciencias experimentales y sociales, 33, 99-122.

Chin, C. and Brown, D. E. (2002). Student-generated questions: a meaningful aspect of learning in science. International Journal of Science Education, 24 (5), 521-549.

Crawford, B. and Capps, D. (2016). What knowledge do teachers need for engaging children in science practices? En J. Dori, Z. Mevarech, D. Baker (eds.), Cognition, Metacognition, and Culture in STEM Education. New York: Springer.

Ferrés-Gurt, Concepció (2017). The challenge for proposing inquiry questions. Revista Eureka sobre enseñanza de las ciencias, 14(2) 410-426.

Harlen, W. (1999). Purposes and procedures for assessing science process skills. Assessment in Education, 6 (1), 129-144.

Mazas, B. y Bravo, B. (2018). Actitudes hacia la ciencia del profesorado en formación de educación infantil y educación primaria. Profesorado. Revista de Currículum y Formación de Profesorado, 22(2), 285-304.

Ponz, A. y Carrasquer, B. (2018). El uso de preguntas en la Enseñanza de las Ciencias por maestros/as en formación de Educación Infantil. En Martínez, C. y García, S. (Ed.), $28^{\circ}$ Encuentros de Didáctica de las Ciencias Experimentales. Iluminando el cambio educativo (pp. 367-371). A Coruña: Universidade da Coruña, Servizo de Publicacións.

Rivero, A., Solís, E., Martín R., Azcárate P. and Porlán, R. (2017). Prospective teachers changing knowledge about teaching science. Enseñanza de las Ciencias, 35.1, 29-52.

Windschitl, M., Thompson, J., Braaten, M. (2008) Beyond the scientific method: Model-based inquiry as a new paradigm of preference for school science investigations. Science Education 92(5), 941-967. 